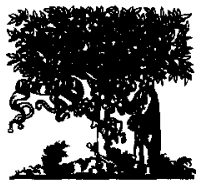

ELSEVIER

\title{
Integrated design and new product success
}

\author{
John E. Ettlie \\ University of Michigan Business School, Ann Arbor, MI 48109-1234, USA
}

Accepted 10 May 1996

\begin{abstract}
Do integrated approaches to design promote the commercial success of new products? Data from 126 U.S. manufacturers were used to test five hypotheses in a structural model of integrated design approaches which go beyond concurrent engineering. New product success was significantly associated with market need understanding which incorporates information, significantly, from integrated design into new product development. Integrated design was found to be significantly associated with early-mover strategy, benchmarking best practices and, to a lesser extent, customized or proprietary hardware-software systems.
\end{abstract}

Keywords: New product development; Title

\section{Introduction}

The majority of industrial $R \& D$ funds are invested for new product introduction and these investments are growing in the U.S. and Japan (Hamilton, 1993; Wolff, 1994). Between 1988 and 1992, U.S. companies substantially increased allocations of R \& $\mathrm{D}$ funds to new product development and, to a lesser extent, increased technical service (Wolff, 1994). There is evidence that R\&D investments do pay off in the majority of industries, especially in pharmaceuticals, consumer products, chemicals and services (Waddock and Graves, 1994), although why some firms make more than others on $R \& D$ is not well known. Firms that derive a greater percentage of their sales from products introduced during the last five years are often the industry leaders, and new

\footnotetext{
${ }^{1}$ Tel.: (313) 936-2835.
}

products have become central to modern competitive strategies among firms around the world (Wheelwright and Clark, 1992).

If timely, new product introduction is so important to manufacturers' success (Schoonhoven et al., 1990; Souder and Sherman, 1994), what strategies and methods make firms good product innovators? Some limited empirical evidence suggests that the simultaneous engineering of product and process does improve design performance in durable goods manufacturing (e.g. Adler, 1989; Ettlie, 1995). But, what accounts for these effects? Are "integrated" design approaches successful? What determines whether or not a firm successfully adopts integrated design practices? These research questions were addressed in the study reported here.

Integrated design is the coordinated development effort in timing and substance of the various disciplines and organizational functions that span the life-cycle of new products and services. This lifecycle starts with research and development or the 
invention and capture of new ideas, and ends with the recycling or disposal of product remnants. The empirical findings of this study of U.S. durable goods product innovators indicate that earlier movers with proprietary computer-assisted design and manufacturing technology, who also benchmark competitors and peers, are more likely to adopt integrated design practices. It was also found that integrated design practices significantly and positively impact better understanding of market needs, which in turn significantly promotes new product commercial success. These new practices go well beyond just the formation and use of teams, to include job rotation and other substantial organizational changes.

\section{The wellsprings of new product success}

While the notion that differentiated, unique product offerings promote success is empirically substantiated in the literature (e.g. Urban and Hauser, 1980; Urban et al., 1987), we know little about how organizations are able to organize to develop products that meet customer needs. There is a growing widespread dissatisfaction in industry with even the most recent methods of coordinated product development, such as concurrent or functionally orchestrated design (e.g. Clausing, 1994, pp. 19-25; Mackey and Carter, 1994).

In this research it is argued that a set of forces that influence firm behavior from the environment (e.g. customers, technology supply, competitors) and internally (e.g. product strategy), combine to instigate unique integrating mechanisms. These integrating behaviors can be used to promote understanding of market needs and enhance the capability to convert market and product ideas into new products ideas that can be acted upon. Once action can be taken in timely fashion, the probability of commercial success is greatly improved. The details of a model to describe this process are discussed next.

\section{New product performance}

Perhaps the most consistent finding in the new product literature is that market need understanding promotes commercial success. Beginning with the
SAPPHO study in the United Kingdom which examined 58 matched pairs of successful and unsuccessful product and process innovations (Freeman, 1974, Freeman, 1982), and followed by numerous other empirical studies (e.g. Maidique and Zirger, 1984; Cooper, 1990), there has been a convergent trend in the wisdom and findings concerning the immediate predictors and correlates of new product success. Knowledge of the market and customer needs usually obtained systematically and directly from potential buyers - is at the top of the list of new product success factors. Product innovativeness and perceived value to customers as well as a balanced approach between marketing and R\&D also are consistent predictors or correlates of new product success (e.g. Link, 1987; Cooper and Kleinschmidt, 1991). This suggests the first hypothesis for testing and replication.

\section{Hypothesis 1. Market need understanding is directly associated with the commercial success of new product launches.}

This hypothesis is not new. But it is included in the model because replication of earlier results will increase confidence in the balance of theory being tested. In addition, and with only a few notable exceptions (e.g. Hise et al., 1989; Barclay and Benson, 1990; Thamhain, 1990; Barclay, 1992), the literature on new product success tells us little about how to achieve effective translation of market and customer needs into ideas or achieve balance in development between what is technically feasible and market relevant. Further, the strategic context (e.g. Burgelman, 1991) of new product and process development tends to emphasize having competence in all technical functions, such as marketing, $\mathrm{R} \& \mathrm{D}$ and production, in place (e.g. Calantone et al., 1993). How to effectively use these skills and talents, as well as how to set the strategic context for successful development of new products, is discussed next.

\section{New product strategy: The early-mover advan- tage}

New product strategy is defined by Cooper (1987) as the "master plan that guides the firm's product 
innovation efforts and links new product development to the corporate plan". One important aspect of this strategy is how much emphasis is placed on being first to market with a new product (Foster, 1986), but it has to be truly better than existing options (Cooper and Kleinschmidt, 1991, Cooper and Kleinschmidt, 1993). The first documented formulations of the first to market strategy appeared in Ansoff and Stewart (1967) who assumed that a "strong R\&D program"' (p. 81) was necessary to support this strategy, which is reinforced by recent work (e.g. Rosenberg, 1990; Ali et al., 1993; Brown and Karagozoglu, 1993).

The most comprehensive recent review on firstmover advantage (and disadvantage) appeared in the marketing literature by Kerin et al. (1992). With respect to technological issues, the authors make the following important points in their literature review: diversified firms have the benefit of scope economics (quick movement among many products sometimes called joint production - in manufacturing); and that product, as well as process technology, learning might account for much of the benefit of any first-mover advantage in any given industry (cf. Rosenbloom and Cusumano, 1987). The evidence for late entrants suffering market share disadvantages for consumer products seems clear even when controlled for differences in marketing effort (Kalyanaram and Urban, 1992). Gabszewicz et al. (1992) found that brand loyalty does confer considerable first-mover advantage, consistent with "hard to follow" results (Wernerfelt and Karnani, 1987; Conner, 1988; Tufano, 1989; Chatterjee and Sugita, 1990).

If sustained market leadership requires technology leadership (Henderson and Clark, 1990; Jelinek and Schoonhoven, 1990; Day, 1994), it challenges an organization to invest in new technical fields which eventually will be complementary (Ettlie et al., 1984; Damanpour, 1991; Prahalad and Hamel, 1990). Although firm size can be a factor, e.g. larger firms seem better able to sustain technology leadership (Methe, 1992), smaller firms can often afford to wait and stay flexible, imitating the best aspects of proven products by quickly following (Wernerfelt and Karnani, 1987). The merits of early followership, freerider benefits (Crawford, 1992) and breadth of market offerings (Kekre and Srinivasan, 1990) have also been debated and studied (Malueg and Schwartz,
1991; Schewe, 1992; McGahan, 1993; Patterson, 1993). Further, Robinson et al. (1992) found that first movers and early movers (market pioneers) differed significantly from later entrants, so the term "early movers"' was adopted for this research.

In order to effectively capitalize on an early-mover strategy and sustain competitive advantage, an emphasis on coordinated effort will be required. Quick response can result from one of three alternative mechanisms: speed up of existing task completion; job simplification, which removes tasks; and elimination of rework before shipping or first production (Lippman and Mamer, 1993; Patterson, 1993; Zahra and Ellor, 1993). Integrated, coordinated action, especially in the new product development cycle, uses all three methods. It coordinates product and process redesign (Ettlie and Reza, 1992), it reduces information uncertainty and false-starts (Adler, 1989; Gales and Boynton, 1992), and it reduces design rework engineering changes that are caused by avoidable mistakes that often result from lack of knowledge about down-stream implications of design decisions. Design rework can account for as much as $40 \%$ of avoidable design revisions (Gries, 1994).

\section{Hypothesis 2. Early - mover product development}

\section{strategic intentions are likely to be}

\section{associated with the adoption of integrated}

\section{design approaches.}

This hypothesis represents the essential focus of the current research: it is proposed that integrated design structures are effective because they capitalize on early-mover strategies as well as coordinate information supplied by the various disciplines involved in new product development. Process technologies tend to be purchased and are widely available to many industry players (Teece, 1988). Therefore, organizations need to provide unique value to customers through timely new products at reasonable cost.

\section{Enabling technologies}

Whitney (1992) reports that Japanese manufacturing companies are in serious pursuit of a strategy to incorporate proprietary computer-aided design 
(CAD), computer-aided manufacturing (CAM) and computer-integrated manufacturing (CIM) software systems as a strategic advantage. The Japanese manager typically depends less on computers and is more dissatisfied with information technology than the U.S. manager (Lohr, 1995). Fowler et al. (1993) found that there is widespread dissatisfaction among Japanese manufacturers with available software to track work-in-process inventories. This would be consistent with the Wernerfelt (1984) resource-based theory explanation of Japanese firm behavior - acquisition of capabilities that are difficult to imitate, and the capture of certain key resources preemptively from competitors. This also explains why Japanese firms form long-term alliances with suppliers (cf. Peteraf, 1993), and integrate marketing and R\&D effectively (Westney and Sakakibara, 1986; Song and Parry, 1992). Further, multiple versions of a technology, like rapid protyping (Miller, 1991) are often available to further capture synergy effects from an existing technology base. The customization of exiting computer-assisted software packages and hardware in manufacturing would accomplish two ends - it would significantly enhance existing administrative innovations such as teams for integrating purposes, by reducing the need for constant face-to-face communications and coordination around standards, and it would make it difficult for competitors to imitate unique integrating practices such as supplier orchestration - both technology and component suppliers.

The adoption of integrated design practices and proprietary software for computerization are likely to go hand-in-hand for successful new-product-launching firms. That is, firms that innovate technically, as well as structurally, are likely to have a considerable competitive edge (Perry, 1990; Susman, 1992). The tailoring of software systems can be viewed as an important prerequisite to restructuring using simultaneous engineering for new product introduction (Whitney, 1992). A few firms have even integrated proprietary software and concurrent engineering directly through expert systems (Thurston, 1993). That is, unless practices and policies evolve that are unique or rare, they are unlikely to be of any competitive advantage (Barney, 1986). Recent examples include the case given by Hague (1994) at Cummins Engine Corporation, where CAD and CAM software is cho- sen carefully from existing supply sources, but then it is integrated with third-party assistance (e.g. university programmers). Cummins' proprietary software is developed to optimize engine performance for environmental (fuel economy, pollution control) and functional performance. Another example is Ford Motor Company's proprietary software support for quality function deployment (QFD) (Miller, 1994). Each of these examples promotes functional integration and unique capability building through learning.

Hypothesis 3. The development of proprietary, customized enabling technologies ( $e . g$. unique $C A D$ ) is likely to be significantly associated with the adoption of integrated design approaches.

\section{Competitive benchmarking}

Competitive pressures force most firms to understand their rivals. This involves both the performance standard comparison and search for new methods. Method benchmarking is a way organizations can monitor environments for competitive practices and this type of information often comes from competitive performance benchmarking exercises (Camp, 1989; Ulrich et al., 1989; Walleck et al., 1991; Karch, 1992/1993; Main, 1992). Benchmarkers search for the best standard in performance and seek information on comparative methods to achieve these standards (Jacobson and Hillark, 1986). If they can adapt these practices to make them unique and difficult to imitate, they are likely to be more successful (Barney, 1986).

McGill and Slocum (1994) include (competitive) benchmarking in their model of organizational learning: successful firms ultimately change their competitive environment with this model. Rare examples of method benchmarking include Marshall (1991). Marshall compared selected product development and manufacturing practices for the instruments and display sections of General Motors' Delco Electronics group with a major Japanese automotive supplier in the same business. The analysis indicated that Delco could save $\$ 12$ million per year with improved process control, the implementation of process standards 
and the use of process-driven design standards (cf. Ulrich, 1992). That is, the source of ideas for changing design-manufacturing integration method and structures can often be adapted from method benchmarking or method benchmarking done within overall comparative benchmarking studies. Companies are very likely to get ideas for new integrating practices as well as other policies and actions from these method benchmarking exercises, and controlling this information among just a few partners reduces the uncertainty of their use and enhances their unique advantage. However, simply copying or attempting to copy methods is unlikely to succeed, as indicated earlier (Barney, 1986).

For new product development, Ettlie and Warner (1992) report that about half of U.S. durable goods companies benchmark on design practices, and these same companies say that they believe that integrating functions is the key to successful new product launch. This is consistent with the hybrid model of autonomous and induced change supported by Burgelman (1991).

\section{Hypothesis 4. The use of benchmarking for methods \\ (e.g. organization structure) as distinct the \\ outcomes (e.g. sales per employee) is likely \\ to be significantlyassociated with the \\ adoption of integrated design.}

\section{Integrated design}

Nevins and Whitney $(1989$, p. 200) say that the only way the conventional, serial approach to design, which hampers communication and coordination, can be avoided is to adopt an integrated approach to product-process design. The integrated approach allows manufacturing engineers, designers, purchasing, etc. the opportunity to work together simultaneously so that the resulting design "would represent an interconnected web of decisions" (Nevins and Whitney, 1989, p. 200), similar to the Wheelwright and Clark (1992, p. 14) notion of "broad expertise in critical functions, team responsibility, and integrated problem solving across functions". Therefore, integrated design is defined as the coordinated de- velopment effort in timing and substance of the various disciplines and organizational functions that span the life-cycle of new products and services. There is some case evidence (Adler, 1989; Stalk and Hout, 1990; Zurn, 1991; Baker et al., 1993) that shows coordinated design effort pays off, but there is only limited broad-based empirical evidence indicating that the link between product and process technologies leads to success (Kim et al., 1992; Susman, 1992; Ettlie, 1995).

Eppinger (1991) and others (Eppinger et al., 1990; Barkin, 1991) have shown the way to simplifying design projects. Eppinger extends earlier work to show that complex design projects can be simplified by creating a matrix of design structure. This matrix is used to show the sequence of technical relationships among design tasks and can also be used to structure teams and subteams in the process and acts as an alternative to eliminating the manufacturing function or market information from the design process.

Integrated design can promote better marketing and customer understanding in two important ways. First, market needs and capabilities are assessed simultaneously, rather than being filtered by gatekeepers and representatives of functions to committees (Souder and Padmanabhan, 1989). Second, delivered quality (both conformance to specifications and satisfaction of customer needs) is potentially quite high because aspiration and reality can be brought together in coordinated development effort. In rare but not totally unknown cases, the customer and supplier are actually part of the integrated design effort (cf. Von Hipple, 1988).

In summary, integrated design approaches can significantly reduce market information uncertainty and task complexity for easier project management and product launch. Therefore, it is argued that by integrating marketing, $R \& D$ and manufacturing, customer needs will be better incorporated into development (Ettlie and Johnson, 1994), which in turn promotes the commercial success of new products. A final hypothesis is offered for testing.

\section{Hypothesis 5. The use of integrated approaches to design is likely to promote the understanding of market needs during new product development .}




\section{Proposed model}

The hypotheses, taken together, are tested in a structural model introduced in Section 10. Overall success of new product launches is hypothesized to be directly associated with market need understanding, and, in turn, integrated design. Early-mover product development strategy, method benchmarking, and adoption of proprietary software for CADCAM-CIM are hypothesized to be associated with integrated design.

\section{Methodology}

A total of 431 eligible, address-screened cover letters and questionnaires (Appendix A) were mailed to randomly selected firms taken from a Compustat tape in August and again in October, 1992 (Sudman, 1976; Sudman and Bradburn, 1982). Durable goods firms were used because they have experienced significant global competition in the last decade. Fifty cases had been eliminated as ineligible (e.g. no longer in business, incorrect tape information for industry category, etc.) in the telephone screening process after mailings. The cover letter was addressed to the chief technical officer (CTO) or chief executive officer (CEO) of the top R\&D performing companies (based on size and $R \& D$ intensity $R \& D$ spent as a percentage of sales) in domestic, durable goods manufacturing. The average $R \& D$ intensity of the sample was $6.8 \%$ ( $s d=6.7 \%, n=$ 120). This is considerably higher than the all-industry average reported by Business Week of $3.7 \%$ (Auderi et al., 1993), but R\&D intensity was not significantly correlated with the other measures in the study, except that these tend to be larger firms.

The pilot-tested questionnaire was divided into two major subparts - background or general information and then information regarding the introduction of the company's "last major new product", in order to avoid selection bias. That is, respondents were not allowed to pick any new product ever introduced by the firm, which might allow them to put a "best foot" forward.

A total of 126 usable questionnaires were returned before the cut-off date of 1 February 1993, for a usable response rate of $29 \%$. Since the resulting $29 \%$ response rate was somewhat below earlier surveys of this type (47\% in Ettlie et al., 1984, and 35\% in Ettlie and Warner, 1992), an evaluation of response bias was undertaken. There was no significant difference (other than expected sample-proportionate industry differences) in respondent versus nonrespondent answers in callbacks to a random sample of two dozen firms for the first five questions on the survey. These five questions covered respondent title, principal products (SIC (Standard Industrial Classification) codes), number of employees, percent shipments out of the country, and outsourcing percertage (see Appendix A).

In a test of responses by SIC code (population vs. sample), SIC codes 20-30 were grouped into one category, 31-34 were grouped, 35, 36 and 37 stand alone, and 38-39 were grouped for cell size reasons. The $\chi^{2}=2.26(p=0.77)$ which is not significant. The population and sample did not differ in response pattern by SIC. In the test of firm size (archival data taken from Compact Disclosure), for population as compared with sample on number of employees, $z=0.84, p=0.19$, n.s. and for firm nonrespondents vs. firm respondents, $z=0.98, p=0.16$, n.s. For net sales, population vs. sample, $z=1.3, p=0.09$, n.s., and for firm nonrespondents vs. firm respondents, $z=1.08, p=0.13$, n.s. Finally, for net sales increase (1988-1992), which is used to validate the dependent variable, for the population versus the sample, $z=0.59, p=0.72$, n.s., and for the nonresponding firms vs. responding firms, $z=0.68, p=0.75$, n.s. (not significant). Therefore, we concluded that the sample and population were not significantly different and that no observable response bias was evident in these data.

To further analyze response bias, and on the assumption that late respondents are like nonrespondents (Johnson et al., 1990), the four questionnaires which were returned after the cut-off deadline of 1 February 1993 were compared with the total sample $(n=126)$ on the first three quantitative questions used for other call-back analysis. The results indicated virtually no difference in average number of employees $(14,291$ vs. 11,040), average exports $(39.5 \%$ vs. $31.6 \%)$ and outsourcing percentages $(45.7 \%$ vs. $49.3 \%)$. 
The frequency distribution of respondents by job title was as follows: (1) general managers, $53(42 \%)$; (2) manager or supervisor, 36 (29\%); (3) engineer, 4 (3\%); (4) staff, 1 (1\%); and (5) missing, $32(25 \%)$. Industries represented were as follows: (1) $25 \%$ electrical machinery (SIC 36); (2) 16\% instruments (SIC 38); (3) 16\% transportation equipment (SIC 37); (4) $12 \%$ machinery (SIC 35). There was no significant difference in the frequency distribution by SIC code in the original list targeted for the survey and proportion of responses by category (see Appendix A for expanded sample characteristics by industry). In all cases, "don't know," or "unavailable" responses were eliminated from the analysis. Scale development is discussed next.

\subsection{Product development strategy: Early movers}

Early-mover strategy was measured using a summed scale of eight items with a Cronbach alpha of 0.72. Five-point, Likert items were used for seven of the question-statements, with strongly agree to strongly disagree response formats. Items included such statements like "recruit the best qualified technical personnel", "first in the industry to introduce new products", and "tradition and reputation ... to be first with new methods". The remaining items were product radicalness statements including "new to the world" status, "breakthrough" status and "revolutionary" status. The section of the questionnaire used to investigate product development strategy was heavily influenced by earlier survey work on new products and process technology (Ettlie et al., 1984; Ettlie and Rubenstein, 1987). Higher scores on this summed scale indicate early-mover strategic intent.

\subsection{Enabling technology: Proprietary development}

The approach taken to measure technology adoption innovativeness was one used by Mohr (1969) and subsequently confirmed by Damanpour (1991) and others as the preferred method. This approach uses multiple firms with multiple technologies with several "states" of adoption. Some were fully using the technology, others only aware of the term. One section on the questionnaire listed out 19 possible technologies and methods that might be used to support within-firm cooperation and coordination for product development. These technologies were adapted from the Society of Manufacturing Engineers Conference Proceedings at AutoFact, in Chicago, 1991. They included "enterprise product definition tools," like IGES (initial graphics exchange specification), "quality management tools," like ISO 9001, "communication standards," like EDI (electronic data interchange), “computing standards," like platform independent software, and "organizational integration tools," like DFA (design for assembly). Proprietary CAD-CAM-CIM technologies were taken as the anchor of this scale using resource-based theories as the guide, and applied work by Whitney (1992) and Ward et al. (1993). A seven-item scale emerged from the factor and item analysis: the adoption of proprietary CAD-CAMCIM; quality management tools - ISO 9002, ISO 9003 and ISO 9004; common user interfaces for computing standards; communication standards usage for EDI, and DCE (distributed computing environment). The Cronbach alpha for the scale was 0.79 (average inter-item correlation was 0.36 ). A summed scale was used for causal modeling.

The response format was designed to allow the respondent to indicate whether or not the particular technology had been adopted and was based on previous survey work (Ettlie et al., 1984): "not-aware (scored 1),' “"aware (scored 2),', "rejected (scored 3)", “in-process of using (scored 4)", “using (scored 5)", and "don't know (counted as missing)". The higher the score the technology achieved, the more likely the firm really understood the technology and was using it, and was able to adopt it in many locations. The merging of technology and quality agendas is obvious in this scale. Perhaps this represents the ultimate technology adaptation in manufacturing.

Where these adoption percentages can be validated with existing, normed results in similar industries, there is remarkable similarity. For example, the adoption of IGES technology was undertaken by 42 of the 126 firms (33\%). The U.S. Department of Commerce survey of over 35,000 establishments projected an adoption rate of $35 \%$ for this and related electronic data interchange technologies in 1988 over the next five years (U.S. DOC, 1989). 


\subsection{Competition: Method benchmarking}

In order to find out about method (versus outcome) benchmarking (Barkin, 1991), the following questions were asked: "Do you benchmark (make visits to other firms and gauge their practices because of their known good reputation) in design approaches?" ("yes" was scored 1 and "no" was scored 0 ); and "Which organizations do you think are good benchmarks in design approaches?' A total of $57(45 \%)$ of the respondents said they benchmarked, $68(54 \%)$ said no, and $1(1 \%)$ was missing. Answers to the second question were used to validate the first. That is, if a company benchmarks, representatives should be able to name their model firm. These results are nearly identical to an earlier survey - about half of durable goods firms in the U.S. method benchmark for new product development (Ettlie and Warner, 1992).

Four other items were included on this scale to gauge benchmarking process and were based on research by Ettlie and Johnson (1994) who found that there was a tradeoff between the benefits of benchmarking and keeping the voice of the customer centered in the new product development. The items were: whether or not the firm or business unit had a program to upgrade the product development process ( $1=$ yes, $0=$ no); and whether or not marketing (for new product development) is a worthwhile investment; how well the marketing contribution is understood for new product development; and finally, whether or not engineering personnel rotate through marketing training. These were five-point Likert type items and for the latter question, less than $10 \%$ of these firms agreed or strongly agreed with this type of rotation statement. The Cronbach alpha for this benchmarking scale was 0.64 (average inter-item correlation was 0.28 ). The standardized item alpha was 0.66 , for mixed format scales. Although one would normally want this reliability measure to be above 0.70 (Nunnally, 1978), the current research has no precedent, so this reliability level is adequate, if appropriate caution is used in generalizations. In addition, coefficient alpha essentially measures the interrelatedness of items (Cortina, 1993). Since individual items but not this scale have been used before (e.g. Ettlie, 1995), it suggests that practices do evolve and change over time. The methods used to integrate functions or disciplines of today may not be those of tommorrow.

\subsection{Integrated design}

Scale development to measure integrated design builds on earlier work (Zurn, 1991; Ettlie and Reza, 1992; Susman, 1992; Ettlie, 1995) used to capture some aspect of actual behaviors and practices used to integrate the design (often research, development and engineering) with manufacturing functions. This effort resulted in a Cronbach alpha of 0.64 . The standardized item alpha was 0.65 .

Although higher internal consistency would be desirable, this scale had adequate properties for inclusion in the causal model and did not have to be corrected for attenuation (Nunnally, 1967, Nunnally, 1978; Lord and Novick, 1968). Many recent articles include scales with Cronbach alpha levels below 0.70 along with higher reliability scales (e.g. Greenwood and Hinings, 1993; Kumar et al., 1993; Ostroff and Schmitt, 1993; Pearce, 1993; Lefkowitz, 1994; Ohlott et al., 1994). Continued scale development for this variable is advised.

The integrated design scale included eight items from previous scales (e.g. Ettlie and Reza, 1992) used to measure design-manufacturing integration: new structures (usually teams) for integration; job rotation; permanent transfer or mobility for engineers and other technical staff; DFA or DFM (design for manufacturing) training; manufacturing sign-off; "CAD for product and purchasing are compatible"; product development team includes outside members (non-engineers...); and new policies or practices in order to integrate design and manufacturing. The four additional items, taken from elsewhere on the survey, asked whether or not firms were using simultaneous engineering for concept development and generating ideas (two items), and two additional personnel movement items involving other functions as well as shared databases: "Do design engineers and purchasing agents/engineers have the same CAD/CAM data base access?" and "Do cost accountants rotate through other positions (e.g. industrial engineering)?"

Response formats for the first eight questions, which probe practices, not attitudes, were scored 3 for "yes", 2 for "in process of adopting", 1 for 
"no", and otherwise missing. Others were scored "yes" = 2, "no" $=0$, and "don't know" as missing. This scale is called the measure of integrated design. A summed score was used for structural modeling, the higher the score, the more integrated practices were used.

Most rare was the use of job rotation: for accounting, 12 cases $(9.5 \%)$ and between engineering functions with only 25 (20\%) firms saying they use it. This is validated by earlier findings which show this practice among the most rare in the U.S. (Ettlie, 1995). Perhaps this adoption rate is low because in U.S. companies this rotation mechanism is typically used for entry-level positions. But future investigation of that assumption is warranted.

\subsection{Technical success}

Among several outcome questions, three items used successfully in earlier surveys (Ettlie and Rubenstein, 1987) were included near the end of the questionnaire for the purpose of gauging technical success: "Was the new product a technical success?" (We define technical success as the achievement of technical performance required in the project specification.) "Was technical success achieved at or very near budgeted cost?" and "Was technical success achieved during the required time period". The response format for both questions was "yes (scored 3)", "too soon to tell (scored 2)", "no (scored 1)" and "don't know (eliminated as missing)". Item and factor analysis produced a three-item scale with Cronbach alpha of 0.55 , and this measure was consequently dropped from further analysis. Perhaps a sufficient number of new products in durable goods are launched before technical success is completely achieved.

\subsection{Market need understanding}

Market need understanding was measured with a summed, four-item scale constructed as modified from Baker and Green (1985) which was originally included in the project origins section of the questionnaire. "How well defined was the user need which this project was intended to fill: at the time the project was initiated; late in the life of the project" (first two questions). And: "How well de- fined was the business purpose of this project: at the time the project was initiated; late in the life of the project" (last two questions).

The response format of each scale item was a seven-choice numbered response labeled "not defined" (for the " 1 " response), "moderately well defined" (for the "4" choice), and "thoroughly defined" (for the " 7 " response number). The Cronbach alpha for this summed scale was 0.79 with an average inter-item correlation of 0.49 . All corrected item-total correlations were in excess of 0.55 for 121 cases.

\subsection{Commercial success}

Commercial success of these new products was measured by responses from three items on the questionnaire: "Overall, was the new product a commercial success (met commercial success expectation)?" Respondents answered "yes", "too soon to tell", "no", or "don't know"; "Which one of the following statements best describes the return on investment (ROI) for the new product to date (circle only one)?": "below total costs", "about equal to operating costs", "about equal to total costs", " moderately above total costs", " a good multiple of investment", and "don't know". The distribution of answers for the first question was 72 for "yes" $(57 \%)$; 39 for "too soon to tell" $(31 \%)$ and 9 for "no" $(8.7 \%)$, with $4(3.2 \%)$ firms not answering (eliminated from the analysis). The third item read "Was market share attained by the new product above, about the same or below expectations?" A factor and item analysis yielded a three-item scale with Cronbach alpha of $0.7 \mathrm{I}$.

The measure of new product commercial success was validated in two ways. First, the measure was directly validated for construct validity by correlating archival measures for sales growth (1988-1992, since most of these new products were introduced in 1990-1991) and the summed (and averaged) scale measure of commercial success. The correlation was significant and in the predicted direction, with $r=$ 0.25 ( $p<0.05$, two-tailed test). Normative data on new product commercial success were used next to validate this measure.

The distribution for commercial success was also validated by results from a review of eight indepen- 
dent empirical studies of product success by Crawford (1987) which found a $40 \%$ new product failure rate to be typical (much lower than most people generally assume). In addition, two recent estimates based on expert opinion and a study of over 11,000 new products puts the success rate at between $56 \%$ (44\% failures) and $65 \%$ (35\% failures) which averaged $60.5 \%$ successes (Power et al., 1993). All ten estimates of new product introduction failure rate converge on the $40 \%$ failure rate. These results suggest substantially high external validity for this item. These items were used successfully and with high internal consistency in previous research on durable goods new product introduction (Ettlie and Rubenstein, 1987).

\section{Results}

Structural model analysis (Hayduk, 1987; Bollen, 1989) using LISREL 7 was conducted (Fig. 1) and the supporting correlation matrix (standardized variables) with raw measure descriptive statistics is presented in Table 1. Technical success, which had insufficient internal consistency, (most likely because the measure used was inadequate), was dropped. Four of the five hypotheses were supported by this causal model.

As predicted by Hypothesis 1, understanding market needs was significantly associated with commercial success of new products $(\gamma=0.286, p=<0.01)$ with significant, explained variance, $R^{2}=8.2 \%$. The other coefficients were not statistically significant in this model, however, early-mover strategy was significantly associated with commercial success in an alternative model (not shown). One of the three exogenous variable pairs was significantly intercorrelated (Fig. 1).

The $\gamma$ for early-mover strategy and integrated design was $0.236(p<0.01)$ which strongly supports Hypothesis 2. Method benchmarking was significantly associated with integrated design $(\gamma=0.286$, $p<0.05$, supporting Hypothesis 4 . However, proprietary CAD-CAM technically failed to produce a significant coefficient using traditional cut-offs $(\gamma=$ $0.135, p<0.10$ ). These three variables (early-mover strategy, proprietary CAD, and method benchmarking) significantly account for $19.3 \%$ of the variance in integrated design.

Integrated design, in turn, was significantly correlated $(\gamma=0.273, p<0.01)$ with market need understanding, with an explained variance of $7.4 \%$. This result supports Hypothesis 5. That is, integrated design practices and market need understanding are key elements in the new product development process associated with commercial success in durable goods.

Mean substitution was used for missing data consistent with recommendations in Roth and Jones (1994) as well as earlier works (e.g. Kalton, 1983; Gilley and Leone, 1991) and no differences were observed in either the multiple correlation coefficients, the correlation matrix (shown in brackets in Table 1), or the structural model, other than the

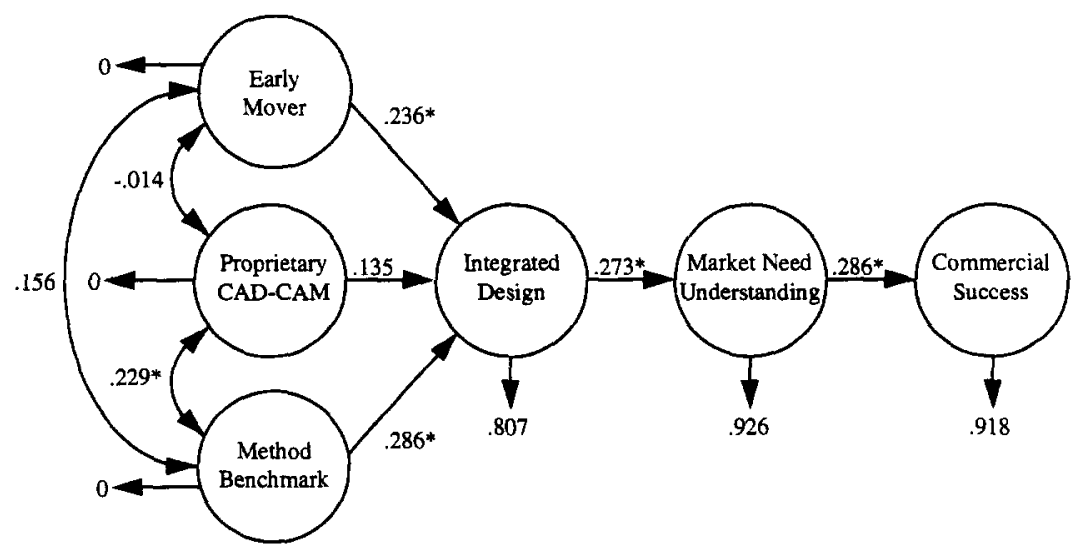

Fig. 1. Structural model results. Summary of goodness of fit tests using LISREL $7.16 ; \chi^{2}$ with 7 degrees of freedom $=9.84(p=0.198)$; AGFI (adjusted goodness of fit index) $=0.926$; root mean square residual $=0.065$; ${ }^{*}$ significant at 0.01 level, two-tailed test. 
Table 1

Correlation matrix (standardized variable measures), descriptive statistics (Pairwise deletion) $[n=126]^{\text {a }}$

\begin{tabular}{|c|c|c|c|c|c|c|c|}
\hline & & 1 & 2 & 3 & 4 & 5 & 6 \\
\hline 1. & $\begin{array}{l}\text { Early-mover strategy } \\
(\bar{x}=26.2 ; s d=5.5 ; n=111) \\
(\bar{x}=26.2 ; s d=5.5 ; n=126)\end{array}$ & $(0.72)$ & & & & & \\
\hline 2. & $\begin{array}{l}\text { Proprietary technology } \\
(\bar{x}=22.4 ; s d=6.1 ; n=109) \\
(\bar{x}=22.4 ; s d=6.1 ; n=126)\end{array}$ & $\begin{array}{l}-0.01[-0.01] \\
(109)\end{array}$ & $(0.79)$ & & & & \\
\hline 3. & $\begin{array}{l}\text { Method benchmarking } \\
(\bar{x}=12.96 ; s d=1.5 ; n=123) \\
(\bar{x}=12.96 ; s d=1.5 ; n=126)\end{array}$ & $\begin{array}{l}0.16[0.16] \\
(110)\end{array}$ & $\begin{array}{l}0.23^{b}[0.23] \\
(106)\end{array}$ & $(0.64)$ & & & \\
\hline 4. & $\begin{array}{l}\text { Integrated design } \\
(\bar{x}=21.3 ; s d=2.7 ; n=90) \\
(\bar{x}=21.3 ; s d=2.7 ; n=126)\end{array}$ & $\begin{array}{l}0.28^{b}[0.28] \\
(81)^{-}\end{array}$ & $\begin{array}{l}0.20^{c}[0.20] \\
(77)\end{array}$ & $\begin{array}{l}0.35^{b}[0.35] \\
(89)\end{array}$ & $(0.64)$ & & \\
\hline 5. & $\begin{array}{l}\text { Market need understanding } \\
(\bar{x}=20.1 ; s d=4.2 ; n=121) \\
(\bar{x}=20.1 ; s d=4.2 ; n=126)\end{array}$ & $\begin{array}{l}0.22^{b}[0.22] \\
(109)\end{array}$ & $\begin{array}{l}-0.01[-0.01] \\
(105)\end{array}$ & $\begin{array}{l}0.24^{b}[0.24] \\
(118)\end{array}$ & $\begin{array}{l}0.27 \text { b }[0.27] \\
(87)\end{array}$ & $(0.79)$ & \\
\hline 6. & $\begin{array}{l}\text { Commercial success } \\
(\bar{x}=9.03 ; s d=1.7 ; n=72) \\
(\bar{x}=9.03 ; s d=1.7 ; n=126)\end{array}$ & $\begin{array}{l}0.19^{c}[0.19] \\
(63)\end{array}$ & $\begin{array}{l}0.01[0.01] \\
(62)\end{array}$ & $\begin{array}{l}0.10[0.10] \\
(70)\end{array}$ & $\begin{array}{l}0.18^{\mathrm{c}}[0.18] \\
(54)\end{array}$ & $\begin{array}{l}0.29^{\mathrm{b}}[0.29] \\
(93)\end{array}$ & $(0.71)$ \\
\hline
\end{tabular}

Mean substitution coefficients indicated in brackets [].

$p<0.01$.

${ }^{c} p<0.05$.

typical increase in explained variances with decreased numbers of observations. The first two equations use a minimum sample size of 87 cases. The last equation (market need understanding and commercial success) has been replicated by literally thousands of data points in the literature (e.g. Maidique and Zirger, 1984; Crawford, 1987; Souder, 1987). The model fits quite well: the $\chi^{2}$ maximum likelihood estimate was 9.84 ( 7 degrees of freedom, $p=0.198$ ) which is not significant, as expected. The goodness of fit index was 0.975 . The adjusted goodness of fit index (AGFI) was 0.926 (Jöreskog and Sörbom, 1989), as shown in Fig. 1. These results indicate very good overall model support.

Not only does the goodness-of-fit result confirm the model, it also can be used to set aside the problems normally encountered with smaller sample sizes and a resulting smaller $\chi^{2}$ value. In addition, many articles have now appeared using smaller samples for at least some hypothesis testing (e.g. Cook et al., 1991; Cook, 1993; $n=53$ and $n=51$, respectively) and maximum likelihood procedures, as were used here. So a minimum sample size in this range is not necessarily problematic.

The practical significance of the low explained variances is difficult to estimate (Johnson, 1995). A five percentage point variance in commercial success of a new product might mean the difference in a profitable year for an entire firm. Further to this point, Abelson (1985) demonstrates and argues that "it is the process through which variables operate in the real world that is important". That is, explanatory factors accumulate in practice and these variables are typically underestimated in importance by variance explanation. In the new product development process, considerable effort is typically expended toward competitive action. A lot is at stake. We know this because most R\&D dollars are spent on new products (Wolff, 1994). To underestimate the impact of these variables in the process would be the greater danger when drawing practical conclusions.

\section{Discussion}

Early-mover product development strategy was found to be significantly related to the use of integrated design approaches (e.g. marketing - R\&D production teams) in a structural equation model. Integrated design was also found to be a significant 
function of benchmarking on the methods of new product development as opposed to, or in addition to, performance benchmarks and, to a lesser extent, dependent upon adoption of proprietary enabling technologies of integration (e.g. CIM). Integrated design was significantly associated with understanding market needs which positively impacted the commercial success of recent, new, durable goods product introductions.

Although many studies have investigated the marketing-R\&D interface, including a recent project using the PIMS data base (Holak et al., 1991), little is known about the marketing-production interface. The results of this study suggest that marketing and manufacturing interact directly in the integrated approach to design. Examples from Von Hipple (1982, Von Hipple, 1988) of engineers, market research and sales personnel visiting customers are a variant on this theme. Although teams are important, they alone may not be enough to ensure new product development success. Strategic direction, integrated design, and knowledge of customers and competitors are all part of the success equation with new products.

This is one of the first times, if not the first time, that survey-based empirical evidence has been reported showing the positive effect of design integrating practices on market need understanding and new product success. Further, the data show how integrating practices within durable goods firms are very much a function of strategies like first-mover tendencies, potential idea sources like benchmarking, and, to a lesser extent, enabling design-manufacturing integrating technology adoption. There was a tendency for proprietary technologies and quality initiatives (ISO 9002-4) to be associated, which suggests an emergent trend of a technology-quality connection for future study. Perhaps broad adoption of all or most of the available integrating technologies is giving way to a very selective refinement and adoption of a select number of available options.

Another important finding of this research is that integrated design approaches appear to be a documented method of strategy implementation for successful early movers, even though results (an alternative structure model) show early movement to be important in its own right. This might explain, in part, why early movers do not always succeed in their strategies. Balanced, resource-based approaches appear to be the key to new product success (Souder, 1987). The results here suggest these practices increase the ability to satisfy customer wants and needs (Ettlie and Johnson, 1994).

Once mastered, do cooperation-enhancing techniques of management become less relevant? After an organization becomes integrated, is co-location and face-to-face interaction less important? Does the technology of integration then take over - like the shift point in a car? This is only suggested in the results, but needs verification. As proprietary software for integration is tailored to a firm's needs, more projects can be incorporated into a program stream. Projects reinforce each other and organizational learning results (Senge, 1990). It would be worth finding out if the capacity for learning is enhanced by the causal sequence supported by the empirical results of this research (Adler, 1992).

Much of what is described and predicted in total by the structural model here amounts to the behavior of firms coping with a complex, uncertain manufacturing challenge. But there is more to manufacturing than discrete products. What can this model do to inform the small batch and process industries? What is the equivalent of the integrated design approach for a chemical firm? Is there a service equivalent for this model? These are questions for future researchers.

The findings concerning the success of early movers as mediated by integrated design also raise new questions about the success of time reduction strategies (Crawford, 1992). Early movement was significantly correlated with new product success, but is joined in the structural model by integrated design. This suggests that early-mover strategies may be a driver to achieve earlier technical success which motivates timely integration of functions. Speed, without the harnessing effect of direction and organizational integration, might only provide marginal advantage in the sustained success equation.

Caution should be exercised in generalizing the results beyond product industries in durable goods and to situations with unique integrating requirements, such as those in globalizing operations. Both the integrated design measure and method benchmarking scales had reliabilities measured by Cronbach alpha in the 0.60 to 0.70 range. The integration scale, in particular, should probably be freshened to 
incorporate new practices (e.g. global, electronically linked teams).

\subsection{Management implications}

Embedded in the results of this research are some important implications for managing the new product development process. First, results imply that earlymover strategies can have an indirect effect on new product success when integrated design practices are in place or if there is a plan to use these practices. Early movement has both a direct and indirect positive impact on new product success. The attacker's advantage might be more sustainable if implemented by integrating organizational practices. Along with a clear front-runner strategy, method benchmarking can significantly help produce some of the ideas needed to make these strategies and technologies work together if it is understood that imitation alone is unlikely to be a sustainable strategy. Yet, there are at least three barriers to smooth implementation of early-mover strategies: new technology development (Schoonhoven et al., 1990), governmental regulation, and the required learning curve to adopt new organizational philosophies. A challenge for smaller firms is to be able to emulate these practices with more restricted resources.

Although benchmarking promotes new product success by supporting integrated design opportunities, there is an inherent difficulty in attempting to benchmark best practices outside a firm. First, leaders are likely to keep proprietary information a secret. Second, even if this information were available, only a capable firm could implement these ideas, and by definition, if one was capable, they would not have to engage in external idea sourcing. There are other, numerous variants on these themes, including idea sourcing with partners, etc., but the resolution to this paradox appears to be that external sourcing of ideas in the absence of capability building is a fruitless exercise. The findings of the current research support this view.

With regard to the central concept and underlying implied practices that support its delivery, integrated design approaches are far from a perfectly understood idea. For example, it is not just a matter of organizing a team for new product development. This is a time-phased, time-dependent process, which changes with each successive new product introduction and this challenges a firm to remain balanced. Many firms have still not overcome the status differential between engineering and manufacturing. How can a balanced, integrated approach be achieved under those conditions? Where are the qualified voices of manufacturing supposed to be found? How should manufacturing management be involved at the beginning of projects? These are some of the challenging strategic issues and questions for the firms represented in the study sample of this research and beyond.

\section{Acknowledgements}

Work in this area was funded by the National Science Foundation under grant No. DDM-907043 and the University of Michigan, Arizona State University and Vanderbilt University. The opinions in this report are those of the authors and do not necessarily reflect the official position of the National Science Foundation. Research assistants on this project were Michael D. Warner, Mark Anderson, Martha Mesa and Peter Swan. Analysis assistance and advice from Professor Richard P. Bagozzi is gratefully acknowledged. Advice from Professor Jeff Edwards is appreciated, and comments by Jim Walsh during revision were helpful. Russell Bush assisted with structural modeling analysis. The comments of two anonymous reviewers are gratefully acknowledged. 


\section{Appendix A. Survey instrument descriptive statisties ${ }^{2}$, product development policies and practices}

\section{A.I. Background, policies and practices}

A.I.1. Company background (to verify some published data)
A. Principal products (SIC codes in U.S.) (See table at end)

B. Current total number of year-round, full-time employees in the firm $\bar{x}=11,040, s d=33,491$ ?, in this business unit $\bar{x}=1493$, $s d=3024$ ? (to verify published data)

C. Percent shipments (business) out of home country. $\bar{x}=32 \%(s d=24 \%)$

D. Please estimate to the nearest five percent the total manufacturing cost represented by purchased and outside costs (material, purchased parts and subcontracts). $\bar{x}=44 \%(s d=21 \%)$

\section{A.1.2. Product development}

$\mathrm{MB}=$ Method Benchmark scale items (also see Section A.2).

MB A. Does your firm or business unit currently have a program to upgrade the product development process? Yes (88\%) No (skip to question 3)

B. What areas does this program cover: (Rank $1=$ most important, etc., for all that apply) 37\% a. quality $34 \%$ b. time to market $1.6 \%$ c. suppliers __ d. plant modernization $8.7 \% \mathrm{e}$. other __ (please name)

C. What is the current life cycle of your main product(s)? $\bar{x}=7.7$ years, $s d=6.9$ years. Projected? $\bar{x}=5.9$ years, $s d=5.7$ years.

D. How long did it take (concept to market) to introduce your last new product? (years) Goal? $\bar{x}=1$ year; $s d=1.3$ years.

E. What percentage of your annual revenues come from products introduced during the last five years? $\bar{x}=49 \%, s d=32 \%$ (average over last 3 years).

\section{A.1.3. The product development process}

ID = Integrated Design scale items; also see below

A. The product development process has often been depicted as a sequences of stages like that below.

$$
\text { Product Concept }- \text { - } \rightarrow \text { Product Plan }--\rightarrow \text { Product Design }-\rightarrow \text { Process Design }
$$

Consider only your last major new product launch that has a track record (no jury out products) when answering the following questions.

Name of the last major new product ___ (10 cases missing). Date launched.

In regards to just the product concept development phase of this product

B. What percentage of total project duration is devoted to concept development? $\bar{x}=16.7 \%, s d=10 \%$

C. What proportion of total project cost is determined by the concept development phase? $\bar{x}=7.9 \%, s d=31 \%$

D. What percentage of total project duration is devoted to product concept, product plan, and product design? $\bar{x}=52 \%, s d=25 \%$

E. What percentage of total project duration is devoted to process design, prototype production, and testing? $\bar{x}=41 \%, s d=21 \%$

ID F. Is simultaneous or concurrent engineering used for concept development? Yes $69.8 \%$

ID G. Is simultaneous or concurrent engineering used for generating ideas before concepts are developed? Yes $46.8 \%$

\section{A.1.4. Product development strategy}

$\mathrm{EM}=$ Early-mover items.

Most companies have tendencies and practices that characterize the way they view new products. Please indicate whether you agree or disagree with the statements below that can be used to characterize your firm's new product development strategy by circling the appropriate response. Circle the appropriate response.

( $\mathrm{SA}=$ strongly agree, $\mathrm{a}=$ agree, $?=$ undecided, $\mathrm{d}=$ disagree, $\mathrm{SD}=$ strongly disagree) [if $\mathrm{SA}=1$ ].

\footnotetext{
${ }^{2}$ Only sections for which study items pertain are included. Most items that were multiple choice were recoded for analysis.
} 
A.

EM B

EM C
We are supporting at least one major alliance or joint venture arrangement specifically to develop or apply new technology to new products.

The first principle in developing new products here is "know how to educate your customer".

We are actively engaged in a campaign to recruit the best qualified technical personnel available in engineering or production.

We always like to be first in the industry to introduce a new product. $\begin{array}{lllllll}\text { SA } & \text { a } & ? & \text { d } & \text { SD } & 2.2 & 1.3\end{array}$

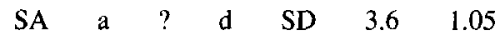

E. We advertise our new processing technology to our customers. $\begin{array}{lllllll}\text { SA } & \text { a } & ? & \mathrm{~d} & \text { SD } & 2.5 & 1.23\end{array}$

$\begin{array}{lllllll}\text { SA } & \text { a } & ? & \text { d } & \text { SD } & 2.3 & 1.19\end{array}$

We have a long tradition and reputation in our industry of attempting to be first to try out new methods and equipment. SA

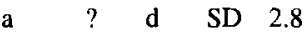

EM G

We are strongly committed to technological forecasting.

(If yes) please name method used:

SA

Which of the following statements best describes your new product?

EM H

$$
\text { (Circle only one). }
$$

Our firm was first in the world to introduce the product $\cdots 1$

Our firm was first in the U.S. to introduce the product $\cdots 2$

Our firm was first in the industry to introduce the product $\cdots 3$

Our firm was second or third in our industry to introduce the new product $\cdots 4$

At the time of introduction, did this new product incorporate technology that was a significant break from past knowledge, technology, or practice in the industry? (Circle only one.)

The most significant breakthrough in the industry for many years $\cdots 1$

A very significant break with the past, but not the most significant $\cdots 2$

It represents an improvement on past technology - not a breakthrough $\cdots 3$

The new product is a modest improvement on current practice $\cdots 4$

The product is similar to competitors offerings with some different features $\cdots 5$

The product is the same or almost the same as our competitors $\cdots 6$

Don't know $\cdots 7$

EM J.

On the following scale, how could you describe the new product?

$\begin{array}{llllllll}\text { Evolutionary 1 } & 2 & 3 & 4 & 5 & 6 & 7 & \text { Revolutionary }\end{array}$ 
A.1.5. Technologies of integration

PT $=$ Proprietary Technology scale items.

During the past two decades many technologies have become available ${ }^{3}$ that may or may not be appropriate for your organization's integration plans. Please indicate whether your organization is: not aware or not considering the technology listed; aware and is considering the technology listed; has considered and rejected the technology; is in the process of installing the technology; or has already implemented the technology, and have it in use.

Please circle the appropriate letters. Use Don't Know if it is not applicable.

Enterprise Product Definition Tools

(1)
A. IGES (Initial Graphics Exchange Specification)
Not-aware Aware Rejected In-Process Using Don't-Know 3.66 1.95
B. PDES (Product Definition Exchange Specification)

Quality Management Tools using the ISO 9000 Standards
C. ISO 9001

PT

D. ISO 9002

PT E. ISO 9003

PT F. ISO 9004

Communication Standards

\section{PT G. EDI (Electronic Data Interchange) \\ H. Paperless Product Development}

PT 1. DCE (Distributed Computing Environment)

Computing Standards

J. Platform Independent Software

K. Interoperability

PT L. Common User Interfaces

\author{
Not-aware Aware Rejected In-Process Using Don't-Know $3.6 \quad 1.2$ \\ Not-aware Aware Rejected In-Process Using Don't-Know 5.5 1.39 \\ Not-aware Aware Rejected In-Process Using Don't-Know $3.4 \quad 1.5$ \\ Not-aware Aware Rejected In-Process Using Don't-Know $3.4 \quad 1.49$
}

Not-aware Aware Rejected In-process Using Don't-Know $3.9 \quad 1.59$

Not-aware Aware Rejected In-Process Using Don't-Know $3.4 \quad 1.81$

Not-aware Aware Rejected In-Process Using Don't-Know $3.99 \quad 1.79$ $\begin{array}{lllllll}\text { Not-aware Aware Rejected } & \text { In-Process } & \text { Using Don't-Know } & 3.9 & 1.7 \\ \text { Not-aware Aware Rejected } & \text { In-Process } & \text { Using } & \text { Don't-Know } & 4.07 & 1.87 \\ \text { Not-aware Aware Rejected } & \text { In-Process } & \text { Using } & \text { Don't-Know } & 4.12 & 1.49\end{array}$

\footnotetext{
${ }^{3}$ See CASA Wheel, Association of the Society of Manufacturing Engineers, Dearborn, MI, and Conference Proceedings, AutoFact (SME) 10-14 November 1991, Chicago, IL.
} 
Organizational Integration Tools
M. DFA (Design for Assembly)
N. DFM (Design for Manufacturability)
O. DFR (Design for Reusability)
P. DFS (Design for Serviceability)
Q. DFD (Design for Disposability)
PT R. Proprietary CAD-CAM-CIM Software
S. QFD (Quality Function Deployment)

$\begin{array}{llllllll}\text { Not-aware } & \text { Aware } & \text { Rejected } & \text { In-Process } & \text { Using } & \text { Don't-Know } & 3.7 & 1.68 \\ \text { Not-aware } & \text { Aware } & \text { Rejected } & \text { In-process } & \text { Using } & \text { Don't-Know } & 4.10 & 1.4 \\ \text { Not-aware } & \text { Aware } & \text { Rejected } & \text { In-Process } & \text { Using } & \text { Don't-Know } & 3.18 & 1.97 \\ \text { Not-aware } & \text { Aware } & \text { Rejected } & \text { In-Process } & \text { Using } & \text { Don't-Know } & 3.64 & 1.72 \\ \text { Not-aware } & \text { Aware } & \text { Rejected } & \text { In-Process } & \text { Using } & \text { Don't-Know } & 3.34 & 2.06 \\ \text { Not-aware } & \text { Aware } & \text { Rejected } & \text { In-Process } & \text { Using } & \text { Don't-Know } & 4.24 & 1.28 \\ \text { Not-aware } & \text { Aware } & \text { Rejected } & \text { In-Process } & \text { Using } & \text { Don't-Know } & 3.65 & 1.79\end{array}$

\section{A.l.6. Design manufacturing integration}

ID = Integrated Design scale items.

Please read the following statements which describe activities that may be used to coordinate the design and manufacturing functions. As part of your new product launch, please indicate if you use any of the following activities to coordinate the design and manufacturing functions.

(1)

ID

ID

ID

C. CAD for product and purchasing are compatible.

ID D. We have a team for product development which includes

OUTSIDE members (non-engineers for example, marketing). (IF YES) Who (by function) is on this team?

ID E. We have implemented new policies or practices in order to integrate design and manufacturing. (IF YES) What are these policies or practices?
(2)

(3)

Yes

No

Yes No

Yes No

In-Process

In-Process

Not Applicable

1.44

Not Applicable $\quad 1.89 \quad 1.08$

Yes No In-Process

Not Applicable

Yes No In-Process Not Applicable $\quad 1.02 \quad 0.9$

ID F. We have developed and implemented new structures in order to coordinate design and manufacturing.

(IF YES) What are these structures?

Ye

No

In-Proces

Not Applicable

1.82

II

G. Job rotation between design and manufacturing engineering is practised in this firm.

Yes No In-Process

Not Applicable

ID

H. Personnel from design engineering are sometimes moved to manufacturing engineering or vice versa.

Yes No In-Process

Not Applicable

1.99

0.69

ID I. Do design engineers and purchasing agents / engineers have the same CAD/CAM data base access?

Yes No Don't Know

$1.5 \quad 0.6$

ID J. Do cost accountants rotate through other positions (e.g. industrial engineering)?
Yes No Don't Know

1.99 


\section{A.2. Origin of the project and realized outcomes and contributions of this new product}

MB = Method Benchmark scale items; $M N U=$ Market Need Understanding items

1. Who first suggested that this project (product) be undertaken? Check more than one box if necessary.

Inside the firm

R\&D Staff

R\&D first-level supervision

$R \& D$ middle management

VP of R\&D

General management

Marketing/distribution/sales

Production

Engineering

Finance

Technical services

Other

Yes
$25.8 \%$
7.9
14.3
19.8
24.6
46.8
2.4
23.8
1.6
0.8

Outside the firm

Customer

- Government representative

- Vendor/supplier

- University consultant

Private consultant

- Technical/professional

colleague, but not paid

consultant

O Other
Yes

$44.1 \%$

3.2

2.4

2.4

3.2

1.6

MNU 2. How well defined was the user need Not which this project was intended to fill: Defined

$\begin{array}{ll}\text { Moderately } & \text { Thoroughly } \\ \text { Well Defined } & \text { Defined }\end{array}$

$\begin{array}{llllllllll}\text { MNU } & \text { At the time the project was initiated } & 1 & 2 & 3 & 4 & 5 & 6 & 7 & \bar{x}=4.3, s d=1.5 \\ \text { MNU } & \text { Late in the life of the project } & 1 & 2 & 3 & 4 & 5 & 6 & 7 & \bar{x}=5.6, s d=1.2\end{array}$

MNU 3. How well defined was the business purpose of this project:

MNU

$\begin{array}{lllllllll}\text { At the time the project was initiated } & 1 & 2 & 3 & 4 & 5 & 6 & 7 & \bar{x}=4.7, s d=1.5 \\ \text { Late in the life of the project } & 1 & 2 & 3 & 4 & 5 & 6 & 7 & \bar{x}=5.6, s d=1.3\end{array}$

4. At the time the project was initiated, who was the intended user? Check more than one box if necessary. Inside the firm

R \& D organization

An organizational unit in the firm with responsibility for this line of business

Marketing/distribution/sales

Production

Engineering

Finance

Technical services

Some other organizational unit not listed above

Other

$\begin{array}{llll}\text { Yes } & \begin{array}{l}\text { Outside the firm } \\ \text { An external customer: }\end{array} & \text { Yes } \\ & \begin{array}{l}\text { Another firm } \\ \text { consumer }\end{array} & \square & 52.4 \% \\ & & \square & 35.7 \\ 3.5 & & \text { other__ } & \\ & & \square & 16.7 \\ 5.1 & \text { Government } & \square & 4.0 \\ 7.9 & \text { Vendor/supplier } & \square & \\ 1.6 & & & \\ 0 & & & \\ 0 & & & \end{array}$

(Circle the best answer.) $[\mathrm{TS}=$ Technical Success scale items; $\mathrm{CS}=$ Commercial Success scale items $]$

TS 1. a. Was the new product a technical success? (We define technical success as achievement of technical performance required in the project specification.)

TS b. Was technical success achieved at or very near budgeted cost?

TS c. Was technical success achieved during the required time period?

CS 2. a. Overall, was the new product a commercial success (met commercial success expectations)?
(1)

(2)

(3) (Missing) $\overline{\mathrm{x}}$ sd

$\begin{array}{cccccc}\text { Yes } & \text { Too soon to tell } & \text { No } & \text { Don't Know } & 1.19 & 0.43 \\ \text { Yes } & \text { Too soon to tell } & \text { No } & \text { Don't Know } & 1.7 & 0.91 \\ \text { Yes } & \text { Too soon to tell } & \text { No } & \text { Don't Know } & 1.69 & 0.95 \\ \text { Yes } & \text { Too soon to tell } & \text { No } & \text { Don't Know } & 1.5 & 0.66\end{array}$


CS b. Was market share attained by the new product above, about the same as or below expectations?

(Circle only one.)

Market share above expectations $\cdots 1$

Market share about same as expectations $\cdots 2$

Market share below expectations $\cdots 3$

Too soon to tell $\cdots 4$

Don't know $\cdots 5$

CS c. Which one of the following statements best describes the return on investment (ROI) for the new product to date? (Circle only one.)

Below total costs $\cdots 1$

About equal to operating costs $\cdots 2$

About equal to total costs $\cdots 3$

Moderately above total costs $\cdots 4$

A good multiple of investment $\cdots 5$

Too soon to tell $\cdots 6$

Don't know $\cdots 7$

3. Were "in process" measures of project performance used for this new product? For example:
a. Number of design change requests before fully released to production? (fill in number) $\bar{x}=19.3, s d=32$
b. Number of actual design change orders actually made after released to production? (fill in number) $\bar{x}=10.9, s d=23$
c. Dependence on supplier(s) reduced
d. Quality improvements (e.g. Cpk, Sigma or scrap \& rework?)
e. Other (Please name)

MB 4. Do you BENCHMARK (make visits to other firms and gauge their practices because of their known good reputation) in Design Approaches?

Yes (45\%)

5. Which organizations do you think are good benchmarks in design approach? 


\section{A.2.1. Marketing}

Please circle the appropriate response regarding marketing's involvement (integration) in the development of the new product in question. Circle the appropriate response. $(\mathrm{SA}=$ strongly agree, $\mathrm{a}=$ agree, ? = undecided, $\mathrm{d}=$ disagree, $\mathrm{SD}=$ strongly disagree)

\section{MB 1. Marketing is a worthwhile investment.}

MB 2. I understand the contribution marketing makes to the product development process.

MB 3. Our engineering personnel rotate through marketing training. [other marketing items deleted]

$\begin{array}{lllllll}\text { SA } & \text { a } & ? & \text { d } & \text { SD } & 4.36 & 0.60 \\ & & & & & & \\ \text { SA } & \text { a } & ? & \text { d } & \text { SD } & 4.15 & 0.69 \\ \text { SA } & \text { a } & ? & \text { d } & \text { SD } & 2.01 & 0.77\end{array}$

Please return this questionnaire in the attached envelope, or Fax to 313-763-5688.THANK YOU!

\section{References}

Abelson, R.P., 1985. "A variance explanation paradox: When a little is a lot", Psychological Bulletin, vol. 97, no. 1, pp. $129-133$.

Adler, P.S., 1989. "CAD/CAM: Managerial challenges and research issues", IEEE Transactions on Engineering Management, vol. 36, no. 3, pp. 202-215.

Adler, P.S., 1992. "Managing DFM: Learning to coordinate product and process design", in: G.I. Susman (Ed.), Integrating Design and Manufacturing for Competitive Advantage, Oxford University Press, New York.

Ali, A., M.U. Kalwani and D. Kovenock, 1993. "Selecting product development projects: Pioneering versus incremental innovation strategies", Management Science, vol. 39, no. 3, pp. 255-274.

Ansoff, H.I. and M. Stewart, 1967. "Strategies for a technologybased business", Harvard Business Review, vol. 45, no. 6, pp. 71-83.

Auderi, R., J. Carey and J. Weber, 1993. “'On a clear day you can see progress: R\&D scoreboard", Business Week, 29 June, pp. 104-124.

Baker, N.R. and S.G. Green, 1985. "Project characteristics product survey', Report, University of Cincinnati, Cincinnati, $\mathrm{OH}$.

Baker, K.R., S.G. Powell and D.F. Pyke, 1993. "Optimal allocation of work in assembly systems", Management Science, vol. 39, no. 1, pp. 101-106.

Barclay, I., 1992. "The new product development process: Past evidence and future practical application", R\&D Management, vol. 22, no. 3, pp. 255-263.

Barclay, I. and M. Benson, 1990. "Success in new product development: The lessons from the past", Leadership \& Organization Development Journal, vol. 11, no. 6, pp. 4-12.

Barkin, P., 1991. "Benefits of structured methodologies in product development programs", presented at the ORSA/TIMS Joint National Meeting, November 3-6, Anaheim, CA.

Barney, J.B., 1986. "Organizational culture: Can it be a source of competitive advantage?", Academy of Management Review, vol. II, no. 3, pp. 656-665.

Bollen, K.A., 1989. Structural Equations with Latent Variables, Wiley, New York.

Brown, W.B. and N. Karagozoglu, 1993. "Leading the way to faster new product development", Academy of Management Executive, vol. VIII, no. 1, pp. 36-47.

Burgelman, R.A., 1991. "Interorganizational ecology of strategy making and organizational adaption: Theory and field research", Organization Science, vol. 3, no. 3, pp. 239-262.

Calantone, R.J., E.A. di Benedetto and R. Devine, 1993. "Organizational, technical and marketing antecedents for successful new product development", R\&D Management, vol. 23, no. 4, pp. 337-351.

Camp, R.C., 1989. "Benchmarking: The search for industry best practices that lead to superior performance", Quality Progress, vol. 22, no. 2, pp. 70-75.

Chatterjee, R. and Y. Sugita, 1990. "New Product introduction under demand uncertainty in competitive industries", Managerial \& Decision Economics, vol. 11, no. 1, pp. 1-12.

Clausing, D., 1994. Total Quality Development, ASME Press, New York.

Conner, K.R., 1988. “'Strategies for product cannibalism"', Strategic Management Journal, vol. 9, Summer, pp. 9-26.

Cook, W.L., 1993. "Interdependence and the interpersonal sense of control: An analysis of family relationships", Journal of Personality and Social Psychology, vol. 64, no. 4, pp. 587-601.

Cook, W.L., D.A. Kenny and M.J. Goldstein, 1991. "Parental affective style risk and the family system: A social relations model analysis", Journal of Abnormal Psychology, vol. 100, no. 4, pp. 492-501.

Cooper, R.G., 1987. "Defining product development strategy", IEEE Transactions on Engineering Management, vol. EM-34, no. 3, pp. 184-193.

Cooper, R.G., 1990. "New products: What distinguishes the winners?', Research-Technology Management, vol. 33, no. 6, pp. 27-31.

Cooper, R.G. and E.J. Kleinschmidt, 1991. "The impact of product innovativeness on performance', Journal of Product Innovation Management, vol. 8, no. 4, pp. 240-251.

Cooper, R.G. and E.J. Kleinschmidt, 1993. "Screening new products for potential winners", Long Range Planning, vol. 26, no. 6, pp. 74-81.

Cortina, J.M., 1993. "What is coefficient alpha? An examination of theory and applications", Journal of Applied Psychology, vol. 78 , no. 1, pp. 98-104.

Crawford, C.M., 1987. "New product failure rates: A reprise", Research Management, vol. 30, no. 4, pp. 20-24. 
Crawford, C.M., 1992. "The hidden costs of accelerated product development", Journal of Product Innovation Management, vol. 9, pp. 188-199.

Damanpour, F., 1991. "Organizational innovation: A meta-analysis of effects of determinants and moderators", Academy of Management Journal, vol. 34, no. 3, pp. 555-590.

Day, D.L.. 1994, "First or best: Competitive advantages of innovation", presented at the Joint Business Policy and Organization \& Management Theory Symposium, "Competitive advantages of innovation", National Academy of Management Meeting, Dallas, TX, 14-17 August.

Eppinger, S.D., 1991. "Model-based approaches to managing concurrent engineering", Journal of Engineering Design, vol. 2, no. 4, pp. 283-290.

Eppinger, S.D. D.E. Whitney, R.P. Smith and D.A. Gebala, 1990. "Organizing the tasks of complex design projects", Proceedings of the ASME 2nd International Conference on Design Theory and Methodology, Chicago, IL, 16-19 September, pp. 39-46.

Ettlie, J.E.. 1995. "Product-process development integration in manufacturing", Management Science, 41(7), July, 12241237.

Ettlie, J.E. and M.D. Johnson, 1994. "Product development benchmarking versus customer focus in applications of quality function deployment'. Marketing Letters, vol. 5, no. 2, pp. 107-116.

Ettlie, J.E. and E.M. Reza, 1992. "Organizational integration and process innovation", Academy of Management Journal, vol. 35, no. 4, pp. 795-827.

Ettlie, J.E. and A.H. Rubenstein, 1987. "Firm size and product innovation", Journal of Product Innovation Management, vol. 4 , no. 2, pp. 89-108.

Ettlie, J.E. and M.D. Warner, 1992. "Good news and bad news on US product development in manufacturing", Proceedings of International Product Development Conference on New Approaches to Development and Engineering, European Institute for Advanced Studies in Management, Brussels, Belgium, 18-19 May, pp. 159-173.

Ettlie, J.E., W.P. Bridges and R. O'Keefe, 1984. “'Organizational strategy and structural differences for radical versus incremental innovation", Management Science, vol. 30, no. 6, pp. 632-695.

Foster, R.N.. 1986. Innovation: The Attacker's Advantage, Summit Books, New York.

Fowler, J.W.. I. Duenyas and L. Schruben, 1993. "Planning and scheduling in Japanese semiconductor manufacturing", presented at the Japan Technology Management Program Research Conference, University of Michigan, Ann Arbor, MI, 21-22 July, p. 20.

Freeman, C., 1974. The Economics of Industrial Innovation, Penguin Books. New York.

Freeman, C., 1982. The Economics of Industrial Innovation, 2nd Edition, MIT Press, Cambridge, MA.

Gabszewicz, J., L. Pepall and J. Thisse, 1992. "Sequential entry with brand loyalty caused by consumer learning-by-using", Journal of Industrial Economics, vol. 40, no. 4, pp. 397-416.

Gales, L.M. and A.C. Boynton, 1992. "Information ties and innovation management: A qualitative assessment of information processing and the strength of weak ties", Journal of High Technology Management, vol. 3, no. 2, pp. 169-188.

Gilley, O.W. and R.P. Leone, 1991. "A two-stage imputation procedure for item nonresponses in surveys", Journal of Business Research, vol. 22, pp. 281-291.

Greenwood, R. and C.R. Hinings, 1993. "Understanding strategic change: The contribution of archetypes", Academy of Management Journal, vol, 36, no. 5, pp. 1052-1081.

Gries, D., 1994. "Integrated product design (at Williams International)", presented at the University of Michigan, Manufacturing Seminar, Ann Arbor, MI, 2 March.

Hague, S., 1994, "CAD, CAM, and integrating (at Cummins Engine Corporation)", presented at the University of Michigan, Manufacturing Seminar, Ann Arbor, MI, 6 April.

Hamilton, D.D., 1993. "US, Japan focusing on electronic gear", Wall Street Journal, 12 July 1993, p. A1.

Hayduk, L.A., 1987. Structural Equation Modeling and LISREL, The Johns Hopkins University Press, Baltimore, MD.

Henderson, R.M. and K.B. Clark, 1990. "Architectural innovation: The reconfiguration of existing product technologies and the failure of established firms"“, Administrative Science Quarterly, vol. 35 , pp. 9-30.

Hise, R.T., L. O'Neal, J.U. McNeal and A. Parasuraman, 1989. "The effect of product design activities on commercial success levels of new industrial products", Journal of Product Innovation Management, vol. 6, no. 1, pp. 43-50.

Holak, S.L., M.E. Parry and M. Song, 1991. "The relationship of $\mathrm{R} \& \mathrm{D}$ sales to firm performance. An investigation of marketing contingencies", Journal of Product Innovation Management, vol. 18, pp. 267-282.

Jacobson, G. and J. Hillark, 1986. Xerox: American Samurai, Macmillan, New York.

Jelinek, M. and C.B. Schoonhoven, 1990. The Innovation Marathon, Blackwell, Oxford, UK.

Johnson, R., 1995, "New Mitsubishi President may be named this week", Automotive News, 24 April, p. 15.

Johnson, M.D., D.R. Lehmann and D.R. Horne, 1990. "The effects of fatigue on judgments of interproduct similarity", International Journal of Research in Marketing, vol. 7, pp. $35-43$.

Jöreskog, K.G. and D. Sörbom, 1989. LISREL7-A Guide to the Program and Applications, 2nd Edition, SPSS, Chicago, IL.

Kalton, G., 1983. Compensating for Missing Survey Data, Survey Research Center, University of Michigan, Ann Arbor, MI.

Kalyanaram, G. and G.L. Urban, 1992. "Dynamic effects of order entry on market share, trial penetration and repeat purchases for frequently purchased consumer goods". Marketing Science, vol. 11, no. 3, pp. 235-250.

Karch, K.M., 1992/1993. "Getting organizational buy-in for benchmarking: Environmental management at Weyerhaeuser", National Productivity Review, Winter, pp. 13-22.

Kekre, S. and K. Srinivasan, 1990. "Broader product line: A necessity to achieve success?", Management Science, vol. 36 , no. 10 , pp. $1216-1231$.

Kerin, R.A., P. Varadarajan, P. Rajan and R.A. Peterson, 1992. "First-mover advantage: A synthesis, conceptual framework 
and research propositions", Journal of Marketing, vol. 56, no. 4 , pp. 33-52.

Kim, J.S., L.P. Ritzman, W.C. Benton and D.L. Snyder, 1992. "Linking product planning and process design decisions", Decision Sciences, vol. 23, pp. 44-60.

Kumar, N., L.W. Stern and J.C. Anderson, 1993. "Conducting inter-organizational research using key informants", Academy of Management Journal, vol. 36, no. 6, pp. 1633-1651.

Lefkowitz, J., 1994, "Sex-related differences in job attributes and dispositional variables: Now you see them, ...", Academy of Management Journal, vol. 37, no. 2, pp. 323-349.

Link, P.L., 1987. "Keys to new product success and failure", Industrial Marketing Management, vol. 16, no. 2, pp. 109-118.

Lippman, S.A. and J.W. Mamer, 1993. "Preemptive innovation", Journal of Economic Theory, vol. 61, no. 1, pp. 104-119.

Lohr, S., 1995, "Study says Japan's executives are behind in technology", New York Times, 15 May, p. C5.

Lord, F.M. and M.R. Novick, 1968. Statistical Theories of Mental Test Scores, Addison-Wesley, Reading, MA.

Mackey, M.A. and J.C. Carter, 1994, "Concurrent engineering: Measure the steps to success", IEEE Spectrum, vol. 31, no. 6, pp. 33-38.

Maidique, M.A. and B.J. Zirger, 1984. "A Study of success and failure in product innovation: The case of the U.S. electronics industry', IEEE Transactions on Engineering Management, vol. 51, no. 1, pp. 192-203.

Main, J., 1992. "How to steal the best ideas around", Fortune, 19 October, pp. 102-106.

Malueg, D.A. and M. Schwartz, 1991. "Preemptive investment, toehold entry and the mimicking principle', Rand Journal of Economics, vol. 22, no. 1, pp. 1-13.

Marshall, D.A., 1991. "Dynamic benchmarking: A comparative study of automotive suppliers", Unpublished Masters Thesis, Electrical Engineering, Computer Science and Management, Massachusetts Institute of Technology, Cambridge, MA.

McGahan, A.M., 1993. "The effect of incomplete information about demand on preemption", International Journal of Industrial Organization, vol. 11, no. 3, pp. 327-346.

McGill, M.E. and J.W. Slocum, 1994. The Smarter Organization, Wiley, New York.

Methe, D.T., 1992. "The influence of technology and demand factors on firm size and industrial structure in the DRAM market, 1973-1988', Research Policy, vol. 21, no. 1, pp. 13-25.

Miller, B., 1991. "Fast prototyping makes models sooner and better", Plastics World, vol. 49, no. 3, pp. 44-47.

Miller, C., 1994. "Using QFD to improve process of automotive painting", Transactions of the 6th Symposium on Quality Function Deployment, Novi, MI, 12-14 June, Goal/QPC and the American Supplier Institute, pp. 521-535.

Mohr, L.B., 1969. "Determinants of innovation in organizations", American Political Science Review, vol. 63, no. 1, pp. 111123.

Nevins, J.L. and D.L. Whitney, 1989. Concurrent Design of Products and Processes, McGraw-Hill, New York.
Nunnally, J.C., 1967. Psychometric Theory, 1st Edition, McGraw-Hill, New York.

Nunnally, J.C., 1978. Psychometric Theory, 2nd Edition, McGraw-Hill, New York.

Ohlott, P.J., M.N. Ruderman and C.D. McCauley, 1994. "Gender differences in managers' developmental job experiences", Academy of Management Journal, vol. 37, no. 1, pp. 46-67.

Ostroff, C. and N. Schmitt, 1993. "Configurations of organizational effectiveness and efficiency", Academy of Management Journal, vol. 36 , no. 6 , pp. 1345-1361.

Patterson, W.C., 1993. "First-mover advantage: The opportunity curve", Journal of Management Studies, vol. 30, no. 5, pp. 759-777.

Pearce, J.L., 1993. "Toward an organizational behavior of contract laborers: Their psychological involvement and effects on employee co-workers", Academy of Management Journal, vol. 36 , no. 5 , pp. 1032-1096.

Perry, T.L., 1990. "Teamwork plus technology cuts development time", IEEE Spectrum, vol. 27, no. 10, pp. 61-67.

Peteraf, M.A., 1993. "The cornerstones of competitive advantage: A resource-based view", Strategic Management Journal, vol. 14 , no. 3, pp. 179-192.

Power, C., K. Kerwin, R. Grover, K. Alexander and R.D. Hof, 1993. "Flops: Too many new products fail. Here's why", Business Week, 16 August, pp. 76-82.

Prahalad, C.K. and G. Hamel, 1990. "The core competence of the corporation", Harvard Business Review, May-June, pp. 7991.

Robinson, W.T., C. Fornell and M. Sullivan, 1992. "Are market pioneers intrinsically stronger than later entrants?', Strategic Management Journal, vol. 13, pp. 609-624.

Rosenberg, N., 1990. "Why do firms do basic research (with their own money)?', Research Policy, vol, 19, no. 2, pp. 165-174.

Rosenbloom, R.S. and M.A. Cusumano, 1987. "Technological pioneering and competitive advantage: The birth of the VCR industry', California Management Review, vol. 29, Summer, pp. $51-76$.

Roth, P.L. and S.D. Jones, 1994. "A conceptual review of missing data techniques for I/O psychologists", presented at the Meetings of the Society for Industrial and Organizational Psychology, Nashville, TN.

Schewe, G., 1992. "The imitation as an option of the management of technology", Proceedings, Management of Technology III, vol. 1, Miami, FL, 17-21 February, pp. 20-28.

Schoonhoven, C.B., K.M. Eisenhardt and K. Lyman, 1990. "Speeding products to market: Waiting time to first product introduction in new firms"', Administrative Science Quarterly, vol. 35 , no. 1 , pp. 177-207.

Senge, P.M., 1990. The Fifth Discipline, Doubleday and Currency, New York.

Song, X.M. and M.E. Parry, 1992. "The R\&D-marketing interface in Japanese high-technology firms", R\&D Management, vol. 9, no. 2, pp. 91-112.

Souder, W.E., 1987. Managing New Product Innovations, Lexington Books, Lexington, MA. 
Souder, W.E. and V. Padmanabhan, 1989. "Transferring new technologies from R\&D to manufacturing", Research and Technology Management, vol. 32, no. 5, pp. 38-43.

Souder, W.E. and J.D. Sherman, 1994. Managing New Technology Development, McGraw-Hill, New York.

Stalk, G. and T.M. Hout, 1990. Competing Against Time, The Free Press, New York.

Sudman, S., 1976. Applied Sampling, Academic Press, New York.

Sudman, S. and N. Bradburn, 1982. Asking Questions, JosseyBass, San Francisco, CA.

Susman, G.I. (Ed.), 1992. Integrating Design and Manufacturing for Competitive Advantage, Oxford University Press, New York.

Teece, D.J., 1988. "Capturing value from technological innovation: Integration, strategic planning, and licensing decisions", Interfaces, vol. 18, no. 3, pp. 46-61.

Thamhain, H.J., 1990. "Managing technologically innovative team efforts toward new product success", Journal of Product Innovation Management, vol. 7 , no. 1, pp. 5-18.

Thurston, D.L., 1993. "Concurrent engineering in an expert system", IEEE Transactions on Engineering Management, vol. 40 , no. 2, pp. 124-135.

Tufano, P., 1989. "Financial innovation and first-mover advantages", Journal of Financial Economics, vol. 25, no. 2, pp. 213-240.

U.S. Department of Commerce (DOC), 1989. "Manufacturing technology 1988', Bureau of Census Report, May.

Ulrich, K.T., 1992. "The role of product architecture in the manufacturing firm", Working Paper \#3483-92-MSA, Alfred P. Sloan School of Management, Massachusetts Institute of Technology, Cambridge, MA.

Ulrich, D., W. Brockbank and A. Yeung, 1989. “Beyond belief: A benchmark for human resources", Human Resources Management. vol. 28, no. 3, pp. 311-335.

Urban, G.L. and J.R. Hauser, 1980. Design and Marketing of New Products, Prentice-Hall, Englewood Cliffs, NJ.

Lrban, G.L., J.R. Hauser and N. Kholakia, 1987. Essentials of New Product Management, Prentice-Hall, Englewood Cliffs, NJ.
Von Hipple, E., 1982. "Appropriability of innovation benefit as a predictor of the source of innovation", Research Policy, vol. 11, no. 2, pp. 95-115.

Von Hipple, E., 1988. The Sources of Innovation, Oxford University Press, New York.

Waddock, S.A. and S.B. Graves, 1994, "Industry performance and investment in R\&D and capital goods", Journal of High Technology Management Research, vol. 5, no. 1, pp. 1-17.

Walleck, A.S., J.D. O'Halloran and C.A. Leader, 1991. "Benchmarking world-class performance", The McKinsey Quarterly, no. 1, pp. 3-24.

Ward, A., D.K. Sobek, J.J. Cristiano and J.K. Liker, 1993. "Toyota, concurrent engineering and set-based design", presented at the Japan Technology Management Program, Research Conference, University of Michigan, Ann Arbor, MI, 21-22 July, p. 31.

Wernerfelt, B., 1984. "A resource-based view of the firm", Strategic Management Journal, vol. 5, pp. 171-180.

Wernerfelt, B. and A. Karnani, 1987. "Competitive strategy under uncertainty", Strategic Management Journal, vol. 8, no. 2, pp. 187-194.

Westney, D.E. and K. Sakakibara, 1986. "The role of Japan-based R\&D in global technology and strategy", Technology in the Modern Corporation, pp. 219-220.

Wheelwright, S.C. and K.B. Clark, 1992. Revolutionizing Product Development, Free Pruss, New York.

Whitney, D., 1992. "State of the art in Japanese computer-aided design methodologies for mechanical products", Office of Naval Research Asian Office, Scientific Research Bulletin, vol. 17 , no. 3 .

Wolff, M.F., 1994. "Meet your competition: Data from the IRI R\&D survey", Research-Technology Management, JanuaryFebruary, pp. 18-24.

Zahra, S. and D. Ellor, 1993. "Accelerating new product development and successful market introduction', SAM Advanced Management Journal, vol. 58, no. 1, Winter, 9-15.

Zurn, J.T., 1991. "Problem discovery function. A useful tool for assessing new product introduction", IEEE Transactions on Engineering Management, vol. 38, no. 7, May. 110-119. 